\title{
The blended learner: digitalisation and regulated freedom - neoliberalism in the classroom
}

\author{
Emiliano Grimaldi* and Stephen J. Ball** \\ * Department of Social Sciences, University Federico II, Naples, Italy \\ ** Institute of Education, University of London, London, UK \\ emiliano.grimaldi@unina.it; s.ball@ioe.ac.uk
}

Emiliano Grimaldi is Associate Professor of Sociology of Education at the Department of Social Sciences of the University of Naples Federico II, in Italy. His work is in education policy sociology and his research has centred on educational governance and evaluation, NPM reforms in education, inclusive education and social justice.

ORCID: Emiliano Grimaldi http://orcid.org/0000-0003-1085-1127

Stephen J. Ball is Distinguished Service Professor of Sociology of Education at the University College London, Institute of Education. He was elected Fellow of the British Academy in 2006; and is also Fellow of the Academy of Social Sciences; and Society of Educational Studies, and a Laureate of Kappa Delta Phi; he has honorary doctorates from the Universities of Turku (Finland), and Leicester. He is co-founder and Managing Editor of the Journal of Education Policy.

ORCID: Stephen J. Ball http://orcid.org/0000-0001-7446-4201

Word count: 10725

Corresponding author: Emiliano Grimaldi - emiliano.grimaldi@unina.it 


\title{
The blended learner: digitalisation and regulated freedom - neoliberalism in the classroom
}

\author{
The digital revolution in education is sustained by the belief that digital \\ technologies carry with them the potential for an ethical renewal of learning \\ according to the neoliberal principle of freedom. In this article we problematise \\ the ethical effects of the encounter between Blended Learning as a techno- \\ educational form and neoliberalism, focusing as an exemplary case on the \\ introduction of an innovative Blended Learning model in a US Charter School \\ funded by the Michael and Susan Dell Foundation. Connecting the literatures on \\ the neoliberalisation and digitalisation of education, we show how in this case it \\ is possible to observe a paradoxical kind of ethical renewal, emerging from the \\ intertwining between the individualizing possibilities opened up by digital \\ technologies, freedom production as a neoliberal project of world-making and the \\ related search for new and specific mechanisms of security. We argue that digital \\ technologies are in a paradoxical relationship with neoliberalism, crystallising the \\ conditions of possibility for a neoliberalisation of education, but also having the \\ potential to betray the promise of educational freedom and differentiation. Far \\ from making any claim of determination, we outline the need for future research \\ that explores the enactment of Blended Learning and questions its effects on \\ education.
}

Keywords: blended learning; digitalisation; neoliberalism; individual learner; philanthropy; governmentality

\section{Introduction}

A growing body of literature in the field of educational research demonstrates how digital technologies are acting as drivers of significant changes to the nature and form of educational provision and practices, producing at the same time new modes of governing and forms of production and consumption of education (Selwyn and Facer 
2013; Williamson 2018). As such, these technologies are part of a wider re-alignment of the relations between the state ${ }^{1}$, schooling, civil society and an expanding field of Edtech providers, corporate investors, advocacy groups and philanthropic actors of various kinds (Ball, Junemann and Santori 2017).

The proliferation of digital educational technologies is promoted by an increasingly powerful industrial complex of EdTech businesses, venture capitalists and philanthropies, investors and reform advocates that is colonising education as a relatively new, dynamic and differentiated market within which profits can be made (Picciano 2013; Ball, Junemann and Santori 2017). The ‘digital revolution' in education is sustained by the general belief amongst many powerful interests, political and commercial, that digital technologies, differently assembled in face-to-face, on-line or blended teaching and learning forms, carry 'with them' the potential for a fundamental ethical renewal of education (Selwyn 2013, 7). Digital technologies are discursively constructed as the solution to the (re)making of education as an effective means to address a vast and heterogeneous array of social and economic challenges, such as the production of a high quality human capital, the elimination of poor educational performance by students in disadvantaged areas, the education for the poor in late developing societies, special needs education, and more generally the personalisation of education (e.g. Moe and Chubb 2009).

As carriers of an ethical re-making of education and new possibilities for profit, digital technologies as techne and as discourse assemble themselves with a distinct set of political rationalities, educational epistemologies and economic interests (Selwyn and Facer 2013). They are part of a wider process of socio-regulatory restructuring of education, whose historical peculiarity lies in the global scale and general ambition of its goals and purposes. This process of restructuring is inherently uneven, contested, 
incomplete and unpredictable. Even so, it is possible to observe the recurrence of 'broader patterns and connections' (Peck and Tickell 2002, 388).

In this article we reflect on a particular encounter within this field of 'broader patterns and connections': between Blended Learning (hereafter $\mathrm{BL}^{2}$ ) as a recurrent and popular techno-educational moving global form designed to re-make education at classroom level, Ed-tech as a field of profit-making and neoliberalism. We conceptualise here neoliberalism as a migratory rationality, a technology and an ethics of governing that works through the production of freedom (Foucault 2010). As such, neoliberalism invites people to be flexible, responsible and self-managing in different spheres of everyday life, establishing at the same time particular kinds of calculative relations 'between the governing, the self-governed and the space of administration' (Ong 2007, 4). Specifically, our emphasis is on the study of neoliberalisation (Peck and Theodore 2002), that is on a process-based analysis of the variable ways in which neoliberalism is enacted through methods and practices of government ${ }^{3}$ and 'interacts with situated sets of elements and circumstances' (Ong 2007, 5). Thus, the encounter between BL, profit-making and neoliberalism is problematised through the analysis of an exemplary case. We focus on the introduction of an innovative BL model in a US Charter School funded by a philanthropic actor, the Michael \& Susan Dell Foundation (hereafter MSDF), which has been legitimated and globally exported as a digital and personalised learning success 'little story'. Addressing the specificities of this encounter, we intend to contribute to the debate on the relations between digitalisation and the transformations of education connecting two distinct literatures: a) the analysis of the neoliberalisation of education (Ward 2012, 74; Peck and Tickell, 2012) and the labour of assembling and re-assembling of socio-material practices through which neoliberal imaginaries are embodied into education; b) recent works that propose a 
reading of $\mathrm{BL}$ as both activities and discourse that are moved, translated, fixed and legitimated through and within globalising micro-spaces by businesses and philanthropic actors who are part of a global education policy community and share a neoliberal policy episteme (Ball, Junemann and Santori 2017, 43).

The article is structured as follows. First, we present our conceptualisation of BL and neoliberalisation, framing the aims of the article and the kind of contribution we intend to offer to the current debate on the relations between digitalisation and the transformations of education. Second, we locate the BL experience at the centre of our analysis within the overall philanthropic activity of MSDF as one actor within a global community of angel investors committed to transform education systems around the world through disruptive, transferable and scalable innovation. Third, we present our case as a laboratory site where it is possible to identify how a particular kind of BL assemblage, that is the 'gathering of heterogeneous elements' (humans, materials, technologies, organizations, techniques, procedures, norms and events) drawn together as a set of classroom practices (Baker and McGuirk 2017, 428), are presented and represented as a profound ethical renewal of education. We discuss this process of ethical renewal, as the emerging effect of the intertwining between: a) a problematisation of $20^{\text {th }}$ century schooling as biopolitical technology based on planning, where a public authority plays the role of decision-maker and masters all the educational processes; b) the possibilities opened up by digital technologies for the making of the learner as a individual unit; c) neoliberalism as a political rationality and its principle of freedom production (and consumption) as a project of world-making and, relatedly, d) the search for new and specific mechanisms of security to the social/educational as a fabric in which the basic units would have the form of free subjects. 
In the concluding section, we argue that our case can be read as a regulatory experiment, where it is possible to observe the crystallising of the conditions of possibility for a neoliberalisation of the experience of education, that is the creation of a field of relations within which the educational experience gains a distinct and paradoxical neoliberal sense. We reflect on some lines of mutation, whose educational and political relevance relates to their potential characterization as small moves that may be scaled up and can contribute over time to a more profound system reengineering across education systems. Far from making any claim of determination about the relationship between digital technologies, BL and neoliberalism, we end the article outlining an agenda for future research, that explores the enactment of BL and questions its ethical promises and its effects on the changing nature of the provision, consumption and government of education.

\section{Blended Learning as a techno-educational moving global form and its ethical effects}

In the contemporary landscape of education, $\mathrm{BL}$ is a recurrent and fashionable solution which is designed and mobilised to innovate education at classroom level and beyond (Bonk and Graham 2006; see also https://www.blendedlearning.org/basics/). BL is increasingly garnering attention from EdTech businesses, philanthropic and non-state actors, who seek to invest in pioneering scalable reform solutions that will transform education systems around the world. Most notably, it appears particularly functional, as a variegated ensemble of 'technology-driven solutions that aim to maximise efficiency and minimise cost in line with discourses of affordability and scalability' (Ball, Junemann and Santori 2017, 71). BL also shapes and carries a set of philanthropic 
ambitions for systemic change, while also delivering personalised, flexible and customised learning experiences.

Analytically, we interpret BL as a techno-educational moving global form (Ong and Collier 2005), that is as a practical and discursive configuration that assembles technological and pedagogical artefacts, schemes, programs, ideas, propositions resting on the following foundations: a) it is a formal education program, where students learn in part through on line delivery of content and instruction, and in part in a traditional brick-and-mortar location; b) students have a partial control over time, place, path and pace of the learning process, but learning itself is supervised and different models vary mainly depending on the combination between autonomy and supervision; c) there is a certain degree of space-time re-structuring of the classroom through digital technologies and new forms of spatial arrangements; d) it incorporates a certain degree of customisation (or personalisation) of the educational provision (Staker and Horn 2012). As Ball, Junemann and Santori $(2017,82)$ have noted, its educational value is expressed in its disruptive capacity to innovate. In this recurrent configuration, BL shows 'a distinctive capacity for decontextualization and recontextualization, abstractability and movement', across diverse educational contexts, bringing at the same time with it the potential for an ethical renewal of education which relates to its specific technical infrastructures and value regimes (Ong and Collier 2005, 11).

Moving from this conceptualisation, we problematize BL as a space of interaction 'delimited by specific technological forms, material [...] infrastructures, circuits of interaction, and situated values' (Ong and Collier 2005, 11), and attempt to reflect on its productive effects as both an educational approach and business model ${ }^{4}$. Specifically, our aim is to address BL as an imagined and actual ethical attempt to project and construct neoliberal education spaces (Brenner and Theodore 2002, 366). 
In doing so, we address a localised assemblage of a BL model funded by a philanthropic actor, the Michael \& Susan Dell Foundation (MSDF) ${ }^{5}$ as part of their engagement with urban education on a global scale. MSDF is one of the world bigger philanthropic 'angel investors' and they refer to themselves as a catalytic funder, providing early stage funding to pioneer "new and scalable ideas and approaches to transform the education systems around the world' (https://www.msdf.org). In the foundation's philanthropic activity it is possible to observe a peculiar intertwining between the financial and the moral at different scales and in different localities in the web of connections and activities unfolding around the foundation. Interestingly, in the last decade, together with other foundations linked to multinational corporations in the technology industry, MSDF has been an interest-driven and particularly active party in the circulation of BL as a silver bullet solution to education problems across the world (Selwyn 2013, 113).

Using MSDF as an entry-point, we intend to reflect on the ways in which, through the enactment of $\mathrm{BL}$, education is made into a domain whose modalities and 'values of individual and collective existence are problematised' and made 'subject to technological, political, and ethical reflection and intervention' (Ong and Collier 2005, 4). Our focus here is the impact of BL on the formulation and reformulation of teaching and learning, assessment and the curriculum, the modalities of the governing of education (Van Dijck, Poell and de Waal 2018, 3), and more generally how as a technoeducational form BL assembles knowledges and technologies that operate to replace what the critics of state schooling see as ineffective time-space-bounded, socio-material and ethical categories, offering a neoliberalism-inspired alternative. This constitutes a substantial ethical reworking of the ontology, epistemology and teleology of education (Dean 2010, 26). 


\section{Blended learning as educational world-making}

MSDF investments in BL are an example of how global philanthropic foundations have been active in contributing to the global legitimacy of digital learning and to building a strong evidence based for its effectiveness and desirability as solution to global educational and social challenges. In the summer of 2011 MSDF launched the Blended Learning Today initiative, funding a cohort of five organisations operating one or more BL schools, with the intention to provide teachers and students with evidence-based knowledge about 'what does work' in different BL models. This was part of the Foundation's wider programme Urban Education, whose basic assumption is that schooling 'can be a transformative experience for low-income students' (https://www.msdf.org/urban-education/). Thus, the general aim of the Urban Education programme is to promote 'access to quality education and improve outcomes for underserved children' and 'deliver great education'. It includes direct and indirect interventions in the US, India and South Africa. Its areas of intervention are education innovation to improve learning outcomes, data-driven education, large-scale school system transformation, digitalisation, investment on most-innovative and successful experiences and the development of a 'third sector' of schools ${ }^{6}$.

The Urban Education programme constitutes a site of emergence and re-iteration of a distinctive problematisation that associates traditional schooling and, implicitly, public education in general with an inability to provide 'high-quality' educational experiences to students or foster innovation or serve the learning needs of children to families. MSDF assigns to itself the role of redeeming public schooling, describing its 
approach as a pioneering enabler of socially just innovation, a risk-taking creator of opportunities:

\footnotetext{
We're not afraid to try new things - in fact, we believe part of the role of philanthropy is to push the envelope and do exactly that (https://www.msdf.org/initiatives/ed-fi-alliance/).
}

In relation to BL, the Foundation's objective was to draw lessons from exemplary experiences 'contributing to the knowledge base for other practitioners and the broader knowledge'. BL was regarded as a potentially scalable solution to be promoted in order to create the conditions necessary for the 'growth of great schools'. The BL initiative included direct investments of more than $\$ 1.5 \mathrm{~m}$ in five US charter management organisations (CMOs) that utilise different models of BL: KIPP LA Schools, Alliance College-Ready Public Schools, FirstLine Schools, Rocketship Education, and Summit Public Schools. To evaluate and report on those experiences of BL, MSDF enrolled 'scientific' institutions and experts in a process to legitimate those experiences as 'good practices'. MSDF commissioned a series of case studies from the Foundation Strategy Group (FSG), a nonprofit consulting firm specialising in strategy, evaluation, and research, and working in global partnerships with foundations, corporations, other nonprofits, and governments to provide advocacy, ideas, and resources for leaders working to create social change. The FSG motto on their website is:

Solving social problems requires leaders from foundations, businesses, nonprofits, and governments to reimagine the systems and relationships that shape our world. 
We strive for a deep understanding of how to create social change (https://www.fsg.org).

Further, MSDF funded a year-long impact evaluation of the five BL models to be carried out by SRI International, an independent nonprofit research institute with a history of more than 70 years in bringing high-impact innovative solutions in different fields (from education to robotics), with the aim to create 'new industries, market value, and lasting benefits to society' (https://www.sri.com).

Notably, the Blended Learning Today initiative further articulates the problematisation of public schooling that underpins the Urban Education programme. It identifies three dimensions that represent both critical issues in relation to ineffective traditional schooling and loci of analysis and intervention, where to look for lessons and gains in relation to BL: the instructional model and the experience of teachers and learners; the operational model, that is the data management system, the human capital structure and the network structure to support BL; and the financial model, i.e. the financial implication of $\mathrm{BL}$ in relation to costs and financial benefits, resource investment and long-term sustainability. Here investing in BL is configured as an activity of world-making to address the educational, operational and financial ineffectiveness of traditional public schooling, and to provide a cost-effective solution to tackle sensible social challenges and, thus, value-for-money.

The exemplary case that we present in this article is one of the MSDF 'investments', the introduction of a BL model at the KIPP Empower Academy $\left(\mathrm{KEA}^{7}\right)$, a free public charter elementary school based in Los Angeles. KEA has been supported by MSDF since 2011 with a grant of more than $\$ 250,000$ to implement its BL model. KEA is run by the independent non-profit CMO KIPP LA and part of the "Knowledge 
is Power Program" (KIPP), one of the largest charter school networks in the US, established in 1994 (125 schools). The KIPP network is linked to the KIPP Foundation, a non-profit supported by several philanthropic foundations and led by a former BL solution developer at Pearson Education and Kaplan Inc. Established in 2007, KEA is pedagogically inspired by the motto: Work Hard. Be Nice. Stay Connected. (https://www.kippla.org/approach/academics-character). It decided to 'go blended' in 2011 when the economic recession deepened and the school found itself facing a $\$ 100,000$ shortfall in its annual budget. It was in this contingency that the school leadership identified the use of technology and a blended learning station rotation model (BLSRM) as a pedagogical response to budget reductions and a means of costsaving. The BLSRM is a model involving students rotating among classroom-based learning modalities and online learning stations. During online learning students sign on to the Blended Learning Management System (BLMS) and encounter a range of off-line and online programs and contents on their Student Launch Pad. The BLMS also offers the possibility to synthesize performance data for teachers (see Staker and Horn 2012).

Methodologically, we have analysed the case of KEA using the lenses of an analytics of assemblage (Ong 2007). We provide a thick description of an assemblage (see Figure 1) between a specific range of knowledge forms, modes of technical intervention, and institutional arrangements, developing a deep and rich picture of 'ways of thinking, questioning, acting, intervening, directing [education] and forming [its] subjects' (Brady 2014, 28; Fox and Alldred 2015). Practically, we have combined documentary analysis, deep and extensive internet searches and online tracing (Ball and Junemann 2012). We have collected a vast array of online audio-visual and textual data on the KEA experience: official documents and evaluation reports, school, philanthropic foundations and EdTech corporations' websites, scientific publications, 
Youtube videos on the enactment of the BLSRM at KEA and video-interviews with KEA headteachers, teachers, technology experts and parents that were available on the KEA Youtube channel and/or other related websites. Online audio-visual and textual data have been analysed through coding (using the NVIVO software), adopting a defamiliarising ethnographic sensibility, that is 'an inductive strategy that grapples with the situated articulation of multiple interacting processes and labours that produce socio-spatial phenomena' such as education (Baker and McGuirk 2017, 434). What we attempted to trace was the relational and interactive configuration of actors, events, materials, and technologies which displays a complex educational spatiality. Treating textual and visual data as ethnographic artefacts that provide a glimpse of the 'labours of assembling' (ibid, 437), our attempt has been to make visible how these multiple components have contingently drawn together in the KEA BLSRM contextual assemblage and what effects they produce on the conditions of possibility for the experience of education (see Figure 1).

Figure 1 - The KIPP Empower Academy 'go blended' assemblage INSERT FIGURE 1 HERE

Using the analytics of assemblage we have explored the intertwining of the economic, the technological and the ethical looking at how digitalisation and digital technologies (relationally) contribute to changing the modality of education delivery and its substance, subjects and telos, providing 'evidence of new technologies of the self and new techniques for shaping an individual's relationship to themselves' (Brady $2014,30)$. We are concerned here with the constitution of teaching/learning as experience and teachers and learners as objects of knowledge, technical intervention, 
politics, and ethical (self-)formation. At the same time, we attempt to understand how $\mathrm{BL}$, as a global form and a situated assemblage, functions 'as a source of tension and dynamism for the forms and values' (Ong and Collier 2005, 10-11) of education and structures a certain kind of educational problems.

Nonetheless, our analysis is underpinned by the awareness that the relationship among the elements in an assemblage is not stable; nor is their configuration reducible to a single logic. BL as a techno-educational form interacts 'with other elements, occupying a common field in contingent, uneasy, unstable interrelationships' (ibid. 12). What we analyse here is the opening up of educational possibilities (and the foreclosing of others), rather than an overarching logic determining the educational experience in a BL environment.

The KEA case is a localised assemblage, an actual and specific articulation of a global form comprising global players, networks of brokers and dealers, donors and recipients, sellers and buyers, who interact in a specific moral and educational economy. It is an actual site where new narratives about what counts as a 'good' education are articulated and validated, new forms of teaching and learning are made thinkable, new voices are given space within educational talk, and new forms of educational participation are made possible.

\section{Changing the experience of education through Blended Learning. A laboratory site for a neoliberalising pedagogy?}

Our mission is to empower our students to be strong in mind, body, and spirit so that they will thrive in middle school, high school, college, and the competitive world. 'Strong in mind' conveys the importance of academic skills (cognitive development); 'strong in body' refers to personal habits (physical development); 
and 'strong in spirit' references the character traits we strive to foster (socioemotional and psychological development). (https://www.kippla.org/empower/).

As an assemblage between a specific range of pedagogical forms, modes of technical and educational intervention, and institutional arrangements, the KEA case represents also a governmental and pedagogical game of truth (Foucault 1997). Independently of the objectives pursued by its players, through this game an educational reality is made actual, education and its subjects are produced as objects to be known and controlled, their subjectivities are shaped, and a certain objectivity is established. As the effect of multiple strategic actions, an ethico-political rethinking of education is at stake here, which connects the problematisation of the ineffectiveness of traditional schooling with the attempt to certify, through data, evidence and objective evaluation, the effectiveness of BL and digital technology as legitimate solution for localised problems but also as a systemic reform strategy that can be exported nationally and globally (see Ball, Junemann and Santori 2017). In the attempt to 'fix' and/or 'disrupt' a supposedly 'broken' school mode through a technology-based approach (Selwyn et al. 2016, 147), BL and digital technology participate to the materialisation and operationalisation of one distinct set of values and interpretations of the educational and social world and the displacement of another.

One common element in the statements circulating along the connections of the assemblage is BL as a technology-driven innovation in curriculum, pedagogy and evaluation. For example, Dreambox's technological products, one of several sources of software used in KEA classrooms, are claimed to 'meet students where they are' and 'at the right level', with adaptive and personalised instruction that promotes student 
decision making and strategy development (http://www.dreambox.com). These claims are set over and against traditional teacher-led pedagogies. Edgenuity and Compass Learning, as purchased by KEA, offer Personalised Learning Solutions to schools that will 'empower students to take ownership of their learning, and offer flexible options for pace, scaffolding, remediation, and acceleration, all within one classroom' (https://www.edgenuity.com/products-and-services/personalised-learning-solutions/). This is echoed at KIPP LA, where the infusion of technology into lessons is both part of the curriculum and functional for the development of faster, further and adaptive learning:

\footnotetext{
At KIPP LA, personalised learning isn't just a buzzword - it's part of the curriculum. All of our schools infuse technology into lessons, allowing teachers to deliver more personalised attention to each student. Adaptive educational software enables students to learn at their own pace, helping them get further, faster. Online tools allow students to explore new topics and expand their horizons, further developing their love of learning (https://www.kippla.org/approach/innovation).
}

In the case of the KEA assemblage 'personalised' and 'technology-infused' BL involves:

- the production of educational freedom through a re-spatialising of the classroom and the re-temporalising of the whole learning process according to the logic of modularisation;

- the re-making of the learner as a regulated autonomous subject according to the model of the firm; 
- a paradoxical movement in this process of 'freedom production', where spaces of freedom are secured through performance data production and management, with freedom becoming visible, categorised and measured and performance being fostered and celebrated over competence (Ball 2017, 23).

The assembling of these heterogeneous elements produces a reengineering of the what, how, who and why of education according to a neoliberal rationality. A new concept of learning emerges here, that uproots or bypasses the values that are fundamental to the $20^{\text {th }}$ Century education, with education becoming more and more and individual affair and an adaptive activity of customised delivery whose aim is to produce differentiation.

\section{The blended classroom and the production of educational freedom}

What has been enacted at KEA is a re-spatialising of the classroom according to the key principle of the (neo)liberal art of government, that is the production of freedom (Foucault 2010). Figures 3 provides an abstract and an actual image of such a process of re-spatialising, whose aim is to enable small group and individualised instruction and dismantle the traditional 'whole class environment', challenging its compulsory alignments. The unitary, collective and 'rows and rank' classroom (Foucault 1995, 146) is split into four sub-spaces or stations, corresponding to four instructional and learning modalities: teacher-led direct instruction, teacher-led intervention, individual desk work and individual computer work. Divided into different groups depending on the subject, students spend their school-time rotating in the four areas of the classroom, with rotations always including enclosure into the area of self-directed learning on individual 
computers, 'which are purposefully located in the classroom to reduce transition time and promote a more integrated learning experience' (Bernatek et al. 2012, 9).

Individual learning is central in this new educational ecology and the four areas of the KEA blended classroom can be understood as functional sites designed to correspond to the need to instruct and supervise, but also to create non-serial spaces of educational freedom, choice and circulation. During self-directed learning on individual computers, students sign on to the Student Launch Pad, connect to the BLMS and encounter a range of online programs (iStation, Compass Learning, Dreambox, learning.com). Students are invited (and expected) to choose and learn 'at their own pace' and 'to explore new topics and expand their horizons'. Using software like iStation, they can extend their learning experience outside the 'bricks-and-mortar' school environment with supplementary instruction at home through a school-home virtual connection (https://www.istation.com). In the blended classroom it is possible to observe the co-existence of pedagogical machineries where the individual (and his/her freedom, choice and preferences) becomes the ultimate criteria in the organising of the educational space and experience rather than 'cells', 'places' and 'ranks' and disciplines (Foucault 1995, 147), and the production of categories is partially re-functionalised to organise a particular kind of freedom, that of the enterprising individual learner.

Figure 2 - The KEA Blended Classroom

\section{INSERT FIGURE 2 HERE}

The KEA teachers describe as follows a 'typical' reading rotation, where a significant 
space is given to self-instruction and individual work:

Students are divided into three ability-based groups, and over the 90 minute class spend 30 minutes at each of three stations around the room. Station one might feature phonics and fluency instruction from a Lead Teacher. At the second station students may work on guided reading with an Intervention Teacher, and at the third, computer-based station students might practice vocabulary using the online programs iStation or Compass Learning. (Bernatek et al. 2012, 10)

This is a move beyond the one-to-many and one-size-fits-all educational regime undergirding schooling in the industrial society (Peters, Besley and Araya 2014, 14), that undermines uniformity and seriality in the provision of education, opens spaces of freedom and targets of instruction to fit every student. There is also an epistemological politics of education in play, where the educational experience (as both provision and consumption) is rendered as a collection of discrete pieces that can be organised and ordered autonomously by a 'free' learner who is moved by a 'maker' ethic, confronting a world made of atomistic building blocks to be rearranged and played with (Maddalena 2014). Educational experience and contents are modularised and turned into a fragmented but 'integrated group of components' which can be differently chosen and assembled 'to form a working system of construction elements' functionally oriented towards the attainment of competences (Höhne and Schreck 2009, 501). As we will see later, this implies that quantitative parameters of time, sequencing and performance become key elements to understand and represent the educational experience, a peculiar form of the commodification of knowledge. Within such a form, the free learner is constructed as 'a figure who is in control of his or her own learning process because he or she is involved in choosing [...] the proper software applications needed for his/her 
learning, and is able to co-determine which content he or she is making use of precisely' (Decuypere 2018, 6). Moreover, she is expected, at least in part, to establish autonomously a certain order of meaning, context and pattern of interpretation to systematise the acquired knowledge. She is 'a figure whose projected activities are largely delineated to the consumption, rather than the production' (ibid. 10) or adaptation of the educational content, with the subjects that he or she can study and his/her possible interests being framed and defined by corporate and transnational educational software designers and unmediated by the teacher. Here the learner both makes up and consumes her freedom, investing in a space of discrete and scarce resources.

With digital technology acting as a new information infrastructure that permits greater customisation and personalisation in the provision and consumption of education, KEA's educational project seeks 'to differentiate instruction and plan curricula with multiple entry points and activities so that each student learns in their zone of proximal development' (Bernatek et al. 2012, 7), accelerating the students forward if they are learning successfully and cycling them back if they are struggling (KEA Principal -https://www.youtube.com/watch?v=SvFOHRUG70g). Children are expected to engage with technology at least in part 'free of any supervision' in a selforganised learning experience (Arora 2010). What is at stake is the creation of an educational space where the educational experience and its related risks are privatised and individual learners can participate in an economic game, that is 'can take on and confront risks' (Foucault 2010, 144). Learners are expected to strive to increase their 'educational capital', activating all the resources they have at their disposal - at school and at home. Equalisation through direct intervention ceases to be an objective and a value, education is re-thought as a game of differentiations that performs its function of 
delivering opportunity and produces its regulatory effects (that of guarantee equal participation in the market and of 'raising all boats' - see Chubb and Moe 1990) on condition that it is left to work through freedom and differences (Foucault 2010, 14243). Nevertheless, this is only one side of a two-faced practice. The description of the rotation provided above offers an interesting insight into how the technology-infused respatialising of the classroom as a form of freedom production, paradoxically intertwines with an intensification of the traditional art of distribution of schooling (Foucault 1995, 141). In the case of BL at KEA, the school disciplinary machine intervenes in the bodies and souls of students in order to make them free but docile individual learners. This is a regulated production of a regulated freedom, through an intensification of the form of individualising, partitioning (ibid. 144) and re-temporalising learning.

At KEA, students are ordered through ability-based dividing practices, on the basis of the 'personalising' pedagogical assumption that 'meeting every student at his or her level means ensuring that no children receive all of their instruction in a whole class environment' (Bernatek et al. 2012, 7). Moreover, in a new highly disciplined economy of time, rotation and circulation is tightly segmented into time-modules, according to the following rhythms and cycles of repetition from $7.15 \mathrm{am}$ to $4.15 \mathrm{pm}$ :

Table 1 - The KEA Blended Classroom economy of time

\section{INSERT TABLE 1 HERE}

This is a new temporal elaboration of schooling, of behaviour and the articulation of body-technology, where circulating technology-connected bodies of free individual learners are organised, positioned, given a direction and prescribed an 
aptitude, a duration and an order of succession. In such an encounter between the respatialisation and re-temporalisation of learning, there is a peculiar reworking of the axis that links the singular and the multiple, with a paradoxical marriage between the intensification of both the 'very embodiment of liberty' and multiplicity in the regulative machine of schooling, and a temporal and hierarchical 'schema of discipline' whose function appears to be that of 'treating multiplicity itself' (Foucault 1995, 149). Treating multiplicity through the production of freedom and discipline, produces a new form of educational sociality which has the power to interpolate learners and teachers as new kinds of social and educational subjects.

\section{The making of the free individual learner}

We want our students to live lives of significance, to be critical thinkers, to be leaders and to be on a trajectory that maximises their potential (KEA Principal).

(https://www.youtube.com/watch?v=n5fFr3E9J-s).

Within the KEA assemblage, as a space of connectivity the learner is a hypostasised subject, with her own ability, learning capacities and aptitudes - 'different students arrive to class each day with a range of abilities, backgrounds, and learning styles' (Bernatek et al. 2012, 7) - and a special relation to self-instruction, where on line selfinstruction is considered as having 'intrinsic benefits' and as giving students a better 'understanding of their own learning' (ibid. 11). At the same time, the learner as a bodytechnology complex becomes a site of the reengineering of subjectivity (and freedom). Digital technologies, and BL as a pedagogical model produce freedom but also offer 
new tools to organise it (see Foucault 2010, 63). Personalisation, as a passe-partout in the contemporary pedagogical global-speak, connects up with digital technology and BL in ethical work that is driven by a libertarian sensibility: technology functions as a 'moralisation' project that broadens the choices and activities at the disposal of individuals, so that they can become more self-determined and self-empowered (Selwyn 2013, 122). The core of self-instruction is not specific knowledge, but rather the development of skills (and powers) of self-organisation, that is individual skills 'that are not tied to specific contents, in effect reflecting a process of pragmatisation of knowledge [and its reduction] to employability' (Höhne and Schreck 2009, 502). Furthermore, BL and digital technology are discursively constructed as key enablers of a 'character and behaviour' formation whose main traits are 'approaching life with excitement and energy', 'feeling activated', 'persistence and resilience', 'curiosity as taking an interest in experience and learning new things for its own sake', 'optimism as expecting the best in the future and working to achieve it', the learner must 'get over frustrations and setbacks quickly' and believe that 'effort will improve [her own] future' (https://www.kippla.org/approach/academics-character).

Figure 3 - The individual learner as body-technology complex at KEA

\section{INSERT FIGURE 3 HERE}

The individual learner, especially during and through self-instruction and the interaction with the 'modularised' supply of educational software on her Launchpad, is expected to work hard, to make an 'all-out' effort to achieve (and close achievement gaps) and 'make good choices' (https://www.youtube.com/watch?v=n5fFr3E9J-s). 
There is a privatisation of the responsibility for learning and the promotion of a newly intensified form of learning:

In January 2012, the school received a grant to purchase iPads. The iPads were used primarily for independent practice using web-based math applications, many of which allowed teachers to assign content (e.g., BrainPOP, Motion Math: Hungry Fish). During the second semester, some teachers allowed their students the choice to use DreamBox or applications on the iPad during their computer-assisted learning rotation (Murphy et al. 2014, 81).

The individual learners are centres of choice, enterprise and calculation, whose fates are 'to be determined by their own skills, initiatives, analyses of risk and individual consumption choices and not by their reliance on the social relationships, obligations or expectations generated' by the school (Ward 2012, 2). As bodytechnology complexes, they become sites of articulation of the 'principle of a theoretically ever-growing use of time', sites of an intensification of 'the use of the slightest moment $[\ldots]$ in its very fragmentation' and of the movement to 'an ideal point at which one maintained maximum speed and maximum efficiency' (Foucault 1995, 154). In summarising the key educational implications of the KEA experience, the MSDF General Report (Murphy et al. 2014, 8) highlights how:

Establishing productive, self-directed learning cultures is important for students to fully benefit from online learning. [...] Setting weekly goals for student progress as a mechanism to focus students and increase productivity was a practice that emerged across the school year in most of the schools in the study. 
Education here is re-made as a field of directly and indirectly technologyenhanced learning consistent with a form of neoliberal education (Ball 2017, 29), where the learner is conceived as homo economicus, 'an entrepreneur of his or her individual learning trajectory, responsible for this trajectory, and in need of the consumption of content offered' (Decuypere 2018, 15) according to a form of new prudentialism (Dean 2010). Interpolated within the micro-management of the learning process, the learner is constituted as a self-activating subject adapted to choice, risk, uncertainty and austerity. However, within the general institutional frame that establishes the rules of the game of learning only certain responses, activities and forms of engagement are appropriate. Here, personalisation means the setting out of 'the most rational framework within which individuals engage in their activities in line with their personal plans' (Foucault $2010,173-74)$. This is a generalisation of the model of the firm playing an economic game, with the basic neoliberal set of tropes of responsibility-investment-improvement that become the 'epistemic' form for the desirable and effective educational experience. Such a game implies 'extending the economic model of supply and demand and investment-costs-profit so as to make it a model of social relations and of existence itself' for education (ibid. 241) or, to put it another way, the extension of the economic logic of the enterprise to the educational understood as a fabric of relations between networked and entrepreneurial selves. BL acts as a means to rationalise educational provisioning by constituting learners (and somehow in a different nuance teachers) as nodes of decision-making and calculation that need to perform the ability to 'manage themselves to be low-risk to themselves' (Carlson 2009, 260). In such a process of subjectivity engineering, prudentialism intertwines with developmentalism, an incontestable belief in the self-determining power of the individual (Selwyn 2013, 138) 
and the establishment of 'the figure of the entrepreneur as the promise of indefinite innovation' (Ball, Junemann and Santori 2017, 76).

The activities of free choice, decision-making and calculation occur within a regulated frame where the hardware and software like iStation, Compass Learning and Dreambox set the conditions for learning and function as machines to arrange the use of time, obviate the linear and homogeneous character of teaching, fill time with different, but ordered activities and impose rhythm and temporal norms on individual students. In the KEA case, the essential role of the educational providers is to define the educational rules of the game (the software providers in the BL case) and the teachers' task is to make sure that they are applied (see Foucault 2010, 201). Here free learning does not mean an educational laissez-faire, but a crafting of free learning according to a discursive chain that begins from competition as a principle of formalisation [work hard, be strong and responsible and activate yourself to succeed] and is animated by the ethical project of shaping the learner as the enterprise unit who is in a state of perennial responsibilisation and activation (that is made of strategic rationality but also desire and emotion). The ethical project is to build up a school where the conditions are created for the multiplicity and differentiation of learners (as adaptive individual enterprises), who freely but adaptively develop plans and projects, objectives and tactics.

We move now to a brief discussion of how students and teachers of the KEA classroom are heavily embedded within a controlling environment where learning trajectories are shaped and controlled by parameters and observatory mechanisms of which the learner is most of the time not even aware.

\section{Securing free learning}


The computers are not intended to replace the teachers. They are intended to focus our attentions better and more systematically on what are the needs of each of our individual children (KEA Lead Teacher -

https://www.youtube.com/watch?v=SvFOHRUG70g).

An intentional but not subjective desire for stability and security seems to drive, as a balancing act, the production of educational freedom and the free individual learner within the KEA BL assemblage. When students use a classroom laptop during selfinstruction rotations and sign on to their personal Student Launch Pad, the BLMS aggregates online content for students and synthesises performance data for teachers. A Teacher Dashboard provides a single access point for teachers to view normalised data reports displayed at the classroom and student level (Bernatek et al. 2012). In fact, teachers have the possibility to observe at a distance students individual work through a teacher dashboard that visualises a new educational reality of students' learning, through the language of learning analytics (see Figure 4). At Junyo, the intermediary/consulting firm and technology vendor that supported KEA in the design of the BLMS, they enthusiastically assert how in the enhancement of classroom learning through technology customised learning goes together with the analysis and review of student progress (http://junyo.com).

Figure 4 - Observing and measuring freedom at KEA

\section{INSERT FIGURE 4 HERE}

Figure 5 provides a picture of the technological infrastructure of the KEA BL model, showing all the possibilities of synchronisation, visualisation, calculation, assessment, 
exporting, reporting and controlling that are enabled by the assemblage between a data mart, educational software as tools of data production and the combination of students and teachers' dedicated application layers (the Student Launch Pad and the Teacher Desktop).

Figure 5 - The BLMS Tech Stack intended function at KEA

\section{INSERT FIGURE 5 HERE}

Here digital technology and BL provide information about the classroom and the students that teachers and the school set out to govern and, in doing so, offer 'knowledge that directs the subjectivities of the individual' (Carlson 2009, 259). As a counter-weight to the production of spaces of educational freedom, free learners and multiplicity, a powerful disciplinary space is re-constituted through the exporting of student performance data mapped to objectives and normalised as needed, or the realtime production of aggregated and individualised performance reports from contents on the Teacher Dashboard. Here a digital analytical space is created, that is 'divided into as many sections as there are bodies or elements to be distributed' and it possible to know 'where and how to locate individuals, $[\ldots]$ to be able at each moment to supervise the conduct of each individual, to assess it, to judge it, to calculate its qualities or merits' (Foucault 1995, 144). The free learner is turned back into an analysable and as such manipulable and docile subject, through the exercise of 'an infinitesimal power' (ibid. 138) that takes a virtual hold upon the subject's learning movements, attitudes and rapidity. The free learner becomes the object of a form of control which is focused on the economy of learning and its self-organisation and the ceremony of exercise, 
employing a codification that partitions learning as closely as possible in terms of time, space and movement. As Foucault put it $(1995,140)$, this is a technology-enhanced form of 'supervision of the smallest fragment of' the educational experience which provides 'a laicised content, an economic or technical rationality for [the] mystical calculus of the infinitesimal and the infinite (ibid.). It allows both the characterisation of the individual as individual and the ordering of a given multiplicity. In the MSDF General Report on the Blended Learning Today Initiative (Murphy et al. 2014, 8), classroom and learning management is identified as a key strategy to ensure the productivity of the free learner in online environments:

\begin{abstract}
Strong classroom/learning lab management practices are critical to ensure student productivity in online environments. Teachers and lab monitors alike stressed the importance of establishing the proper academic culture, norms, and behavior management practices for a blended learning model to be successful. This is especially important in managing student transitions between online and teacherled instructional blocks, particularly with younger children.
\end{abstract}

There is a data double here, where the free learner is shaped 'as someone who can be monitored and who can be experimented upon' and at the same time data defines 'what learning is or might be' (Decuypere 2018, 12). Through such a double, a form of indirect guidance of learning activity is enacted, with learning being defined as 'what can be measured and what is producing added value, and is hence always necessarily output-oriented' (ibid). Within this exercise of isolating and distributing individual subjects in a space of performance, the subject disappears and is replaced by a collection of performance indicators, parameters and learning analytics, and a hierarchical ordering of ability groups. Here learners, as an educational population, 
become in the 'naturalness' of their educational performance 'constantly accessible to agents and techniques of transformation, on condition that these agents and techniques are at once enlightened, reflected, analytical, calculated and calculating' (Foucault 2009, 70-71).

There is a transposition of the game of freedom and security which is at the heart of the economy of power of the (neo)liberal art of government to the field of education. Digital technologies make possible the realisation of the ethical project of neoliberalism, the making of the responsible self-learner, they also open-up new possibilities to control that relate individual choices to the collective interest, in this case the making of the entrepreneurial-responsible learner and the making of human capital of good quality (Henman and Dean 2010; Peters, Besley and Araya 2014). Digital devices, BL and the related pedagogical machinery act here as part of a mechanism of governing education 'with the function of producing, breathing life into, and increasing freedom, of introducing additional freedom through additional control and intervention' with control becoming the mainspring to freedom (Foucault 2010, 67).

\section{Conclusion}

With this article we intend to contribute to the analysis of the relations between digitalisation, the emergence of new forms of government, production and consumption of education and the increasing role played by philanthropies and edTech businesses within the contemporary technologically-mediated global re-imagining of education (Ball, Junemann and Santori 2017; Saltman 2010). In doing so, we have focused on BL as one popular techno-educational moving global form, that assembles together a distinct set of knowledges, technologies and ethics, and looked at philanthropic 
investments in BL as a space for the re-imagination of education and society.

More specifically, the aim of the article has been to address as a problem the general belief that digital technologies and technologically-mediated pedagogic forms like BL carry with them the potential for a fundamental ethical renewal of education. A renewal which promises more educational freedom, personalised learning, more equity and greater effectiveness in education.

In problematising such a narrative, through an examination of a philanthropicfunded BL experiment, we seek to question the kind of ethical work the BL pedagogical model has the potential to bring into existence. We show how BL and digital technologies are being enacted as part of an assemblage that crystalizes the conditions of possibility for the neoliberalisation of the experience of education. In our case, in fact, the BL assemblage remakes the world of education, and learning specifically, in the form of an economic game, mediating and softening neoliberalism 'recruiting subjects and institutions into a moral economy that works discursively through assumptions about moral care and agency but which looks, ultimately to the market for its answers' (Mitchell and Lizotte 2014, 89). Moreover, BL and digital technologies are means and amplifiers of a peculiar form of governing at a distance that is individualising and totalising at the same time, where power functions in the capillary of education, effecting the individual and the body of the learner materially in the everyday spaces of education and works primarily through a social norm that shapes the ways of thinking, behaving and feeling of students (see Carlson 2009, 258).

As a social experiment of neoliberalisation, this re-crafting starts from an ethical and political problematisation of traditional planning-based schooling and its ethical grammar. As such the traditional school is framed as a 'black hole into which [public] money is poured' (Apple 1998, 81) and as an apparatus inhibiting liberty and creating 
dependency and 'moral decay' (Ward 2012,3). A re-design of the liberal arts of governing is established to revitalise an anti-institutional and constructionist ethos built around an individualised notion of learning - with the individual learner responsible for co-ordinating and directing their own educational experiences (Selwyn 2013, 138).

Of course, we are not claiming that the relationship between digital technologies, BL as a global form and the neoliberalisation of the educational experience is totalising and determining. We have analysed a singularity and we are framing our conclusion as a discussion of conditions of possibility, that is of set of relations within which the educational experience gains a distinct sense. As an assemblage, $\mathrm{BL}$ is always under construction and there are multiple translations, flows and modes of re-contextualisation. Nevertheless, BL is a minor history that addresses itself to the 'big' questions of education, education politics and policy (Ong and Collier 2005, 15). BL and digital technologies act successively or simultaneously within the intertwining between the local and the global, and contribute to form new contours or surfaces in the topologies of education.

Thus, we end this article with some reflections on the potential lines of mutation that this activity of technologically-mediated ethical 'world-making' in the field of education has the potential to produce and the outline of an agenda for future research.

The first line of mutation relates to shifts in power relations between the players involved in the governing and provision of education (i.e. state, for-profit, philanthropy, edu-tech enterprises, technology providers, public and private schools, teachers and learners). In our case, the assemblage we have analysed involves fundamental changes to who is entitled to govern, and which are the authoritative voices in policy conversations, to the modalities of the education service delivery. Here a heterarchical space is produced within which educational contents and pedagogies as well as 
educational policies/reforms are imagined and made and sold. In the emergence of the assemblage of 'political rationalities, spatial imaginaries, calculative practices, and subjectivities' (Ball 2016, 14) that characterizes our case, what is at stake is both a transformation of the governing of education and the modalities of service delivery, and the re-making of the subjects of education. A puzzling intertwining between education reform and profit can be observed in the case of KEA, where the processes of commodification and privatisation of education and education policy-making nurture and are mutually nurtured by an ethical activity of education world-making. The key problem that our case raises for future research relates, in our view, to the re-allocation of authority in relation to 'manoeuvrings around how education (students, parents, schools, teachers) should be governed, by whom, to what ends and with what means' (Ball 2016, 13). A new set of corporate and 'distant' educational content providers become key actors in school planning and the construction of student learning experiences, selling to states, administrators, schools, teachers, parents and students the 'digital dream' and the promise of relentless curricular and pedagogical change, innovation and alignment to present and future societal knowledge needs (Buckingham, Scanlon and Sefton-Green 2003). Complex and dynamic commercial and market relationship are being forged between those who manage educational institutions, the teaching profession and 'those who deliver the needed educational products', with teachers being treated more as [technical implementers] rather than 'partners in shared governance or autonomous professionals' (Ward 2012, 8).

A second parallel line of mutation relates to changes in what is and what counts as education, what it means to be educated, who educational subjects are and what attributes, aspirations and capacities they are expected to have. In the assemblage we have analysed BL acts as a key device in the unfolding of a game of truth, where what is 
at stake is the transformation of education as a biopolitical technique according to the key forms of the neoliberal rationality, the market, the enterprise unit, the economic game and the trope set responsibility-investment-improvement. This makes actual 'a new social form where markets and minds would increasingly be aligned' (Ward 2012, 10; Olmedo, Bailey and Ball 2013). What is established here, at least in part, is free learning as the organising and regulating principle of education; a principle that enables difference and the game of differentiation to act as regulatory mechanism. BL and digital technologies make visible a realistic, cost-effective, profitable and globally exportable possibility of change to the inner texture of educational practice and its ethical core.

In this respect, there is the need for future research that better explores the nuances of the encounter between the pedagogy of BL, digital technologies and neoliberalisation, looking at the singularities of the intertwining of discipline with governmentality (Foucault 2010, 248). Going blended at KEA involves a technologically mediated embedding of the routines of the neoliberal aesthetic of existence into the everyday life of the school and the classroom (Ball 2017, 23). The learner is 'reconceptualised less as socially connected [student of a classroom] or morally situated member of a culture and more as self-interested competitor, selfactualised entrepreneur and rational consumer in a dynamic and ever-changing [educational] marketplace' (Ward 2012,2). BL and the practices of modularisation act here as pedagogical instruments used to develop students' abilities, but also as a political technology that produces 'an attitude or a habitus of pragmatic utilitarian knowledge, a market value consciousness' (Höhne and Schreck 2009, 503).

In addition to a commodity to be sold in ever-more profitable markets, digital technology becomes a necessary part of a better performing and more ethical 
educational infrastructure that opens possibilities for educational freedom and personalised learning, self-activation, responsibilisation and realisation. In the KEA assemblage the ultimate purpose of the blended classroom is not 'to make sure that students accumulate a certain body of knowledge or practice certain fundamental skills, but to demonstrate that they can be independent constructors of their own experiences and assume responsibility for their own decisions and choices' (Carlson 2009, 266). We are not arguing that this in itself is bad, but rather that it might be dangerous. Here, education is re-conceptualised as a private investment in 'human capital' made by knowledge consumers in order to better their position and status in the marketplace (Ward 2012, 5). Education changes its basic nature, with the learner much less involved in a relation with a teacher, and more and more a stand-lone-learner whose interlocutor is the digital technology itself. This is a new power relation that requires to be addressed in all its micro-physical nuances. BL is a kind of modern educational hybrid, that organises the desire of the individual learner and its power of choice, as requirements of control and conditions for new possibilities of liberation and self-education (Deleuze 1979, xvii; Ball 2017). The KEA assemblage and the school actualised within it are hybridised and incoherent. Paradoxically, forms of power intersect, both to constitute free learner subjects and to secure such a multiplicity. In this respect, our analysis suggests ways in which BL and digital technologies offer and at the same time betray their promise to produce and guarantee educational freedom, personalised learning and differentiation. There is an increase in standardisation, design and evaluation at a distance, external scrutiny and control in and of the educational experience that coexists with 'an almost emphatic embrace of a concept of subjectivity which incorporates powers of self-organisation, individual competence, permanent mobilisation and individual responsibility' (Höhne and Schreck 2009, 503). 


\section{Acknowledgements}

We are very grateful to the two anonymous reviewers for their stimulating and constructive comments and suggestions on the early draft of this article.

\section{References}

Apple, M. W. 1998. Under the New Hegemonic Alliance: conservatism and educational policy in the united States. In Education and change in the Pacific rim: Meeting the challenges, edited by K. Sullivan. Oxford: Symposium Books Ltd, 79-100.

Arora, P. 2010. Hope- in- the- Wall? A digital promise for free learning. British Journal of Educational Technology, 41(5): 689-702. DOI: 10.1111/j.14678535.2010.01078.x

Ball, S. J. 2012. Global Education Inc. London: Routledge.

Ball, S. J. 2016. Following policy: networks, network ethnography and education policy mobilities. Journal of Education Policy, 31(5): 549-566. DOI: 10.1080/02680939.2015.1122232

Ball, S. J. 2017. Foucault as Educator. London: Springer.

Ball, S. J., Junemann, C. and D. Santori. 2017. Edu. Net: Globalisation and Education Policy Mobility. London: Routledge.

Baker, T. and P. McGuirk. 2017. Assemblage thinking as methodology: commitments and practices for critical policy research. Territory, Politics, Governance, 5(4): 425-442. DOI: 10.1080/21622671.2016.1231631

Bernatek, B., Cohen, J., Hanlon, J. and M. Wilka. 2012. Blended Learning in Practice: Case Studies from Leading Schools. KIPP Empower Academy. Michael and Susan Dell Foundation (retrieved at https://www.msdf.org/case-studies/blendedlearning-today/).

Blowfield, M. and C. S. Dolan. 2014. Business as a development agent: evidence of possibility and improbability. Third World Quarterly, 35(1): 22-42. DOI: $10.1080 / 01436597.2013 .868982$

Bonk, C. J. and Graham, C. R. eds. 2006. The handbook of blended learning: Global perspectives, local designs. San Francisco: John Wiley \& Sons. 
Buckingham, D., Scanlon, M., and J. Sefton-Green. 2003. Selling the Digital Dream: Marketing Educational Technology to Teachers and Parents. In ICT, Pedagogy and the Curriculum. Subject to change, edited by Loveless, A. and V. Ellis. London: Routledge, 20-40.

Carlson, D. L. 2009. Producing Entrepreneurial Subjects: Neoliberal Rationalities and Portfolio Assessment. In Governmentality Studies in Education, edited by M. A. Peters, A. C. Besley, M. Olssen, S. Maurer and S. Weber. Rotterdam: Sense Publishers, 257-270.

Chubb, J. E. and T. M. Moe. 1990. Politics, Markets, and America's Schools. Brookings Institution Press.

Dean, M. 2010. Governmentality: Power and Rule in Modern Society (second edition). London: Sage.

Decuypere, M. 2018. Open education platforms: Theoretical ideas, digital operations and the figure of the open learner. European Educational Research Journal, 122. DOI: $10.1177 / 1474904118814141$

Deleuze, G. 1979 Foreword: The Rise of the Social. In J. Donzelot, The Policing of Families. New York: Pantheon.

Foucault, M. 1995. Discipline and Punish. The Birth of the Prison. New York: Vintage Books.

Foucault, M. 1997. Michel Foucault: ethics, subjectivity and truth. In Rabinow, P. (ed.) The essential works of Michel Foucault 1954-1984, Vol 1. London: The Penguin Press.

Foucault, M. 2009. Security, Territory, Population: Lectures at the Collège de France 1977-1978. Basingstoke: Palgrave Macmillan.

Foucault, M. 2010. The Birth of Biopolitics: Lectures at the Collège de France 19781979. Basingstoke: Palgrave Macmillan.

Fox, N. J. and P. Alldred. 2015. New materialist social inquiry: designs, methods and the research-assemblage. International Journal of Social Research Methodology, 18(4): 399-414. DOI: 10.1080/13645579.2014.921458

Gilbert, J. 2013. Neoliberal Networks: a Response to William Davies. OpenDemocracy, available at: http://www.opendemocracy.net/jeremy-gilbert/neoliberalnetworksresponse-to-william-davies (Accessed: 5 May 2014).

Henman, P. and M. Dean. 2010. E-Government and the Production of Standardised Individuality. In Calculating the Social: Standards and the Reconfiguration of 
Governing, edited by V. Higgins and W. Larner. Palgrave Macmillan, London, 77-93.

Höhne, T. and B. Schreck. 2009. Modularised Knowledge. In Governmentality Studies in Education, edited by M. A. Peters, A. C. Besley, M. Olssen, S. Maurer and S. Weber. Rotterdam: Sense Publishers, 499-508.

Lemke, T. 2007. An indigestible meal? Foucault, governmentality and state theory. Distinktion: Scandinavian Journal of Social Theory, 8(2): 43-64. DOI: 10.1080/1600910X.2007.9672946

Maddalena, S. K. 2014. Mediating Atomistic Ontologies: LEGO, Synthetic Biology, and a Digital Episteme. Dissertation submitted to the Graduate Faculty of North Carolina State University.

Mitchell, K. and C. Lisotte. 2014. The grassroots and the gift: Moral authority, American philanthropy, and activism in education. Foucault Studies, (18), 6689. DOI: $10.22439 /$ fs.v0i18.4652

Moe, T. M. and J. E. Chubb. 2009. Liberating learning: Technology, politics, and the future of American education. New York: John Wiley and Sons.

Murphy, R., Snow, E., Mislevy, J., Gallagher, L., Krumm, A. and X. Wei. 2014. Blended Learning Report. Michael \& Susan Dell Foundation (retrieved at https://www.msdf.org/wp-content/uploads/2016/01/MSDF-Blended-LearningReport-May-2014.pdf).

Ong, A. 2007. Neoliberalism as a Mobile Technology. Transactions of the Institute of British Geographers, 32 (1): 3-8. DOI: 10.1111/j.1475-5661.2007.00234.x

Ong, A. and S. J. Collier, eds. 2005. Global assemblages: Technology, politics, and ethics as anthropological problems. Oxford: Blackwell Publishing.

Peck, J. 2010. Constructions of Neoliberal Reason. Oxford: Oxford University Press.

Peck, J. and N. Theodore. 2012. Follow the Policy: A Distended Case Approach. Environment and Planning-Part A, 44 (1): 21-36. DOI: 10.1068/a44179

Peck, J. and A. Tickell. 2002. Neoliberalising space. Antipode, 34 (3): 380-404. DOI: $10.1111 / 1467-8330.00247$

Peters, M. A. 2001. Education, enterprise culture and the entrepreneurial self: A Foucauldian perspective. Journal of Educational Enquiry, 2 (2), 58-71. https://www.ojs.unisa.edu.au/index.php/EDEQ/article/view/558/428

Peters, M. A., Besley, T. and D. Araya, eds. 2014. The New Development Paradigm: Education, Knowledge Economy and Digital Futures. New York: Peter Lang. 
Saltman, K. J. 2010. The Gift of Education: Public Education and Venture Philanthropy. New York: Palgrave Macmillan.

Selwyn, N. 2013. Education in a Digital World. Global Perspectives on Technology and Education. New York: Routledge.

Selwyn, N. and K. Facer, eds. 2013. The Politics of Education and Technology. Conflicts, Controversies, and Connections. New York: Palgrave Macmillan.

Selwyn, N., Nemorin, S., Bulfin, S. and N. Johnson. 2016. Toward a digital sociology of school. In Digital sociologies, edited by J. Daniels, K. Gregory and T. McMillan Cottom. Bristol: Policy Press, 143-158.

Terranova, T. 2015. Securing the Social: Foucault and Social Networks. In Foucault and the History of Our Present, edited by S. Fuggle, Y. Lanci and M. Tassioli. London: Palgrave Macmillan, 111-127.

Van Dijck, J., Poell, T., and M. de Waal. 2018. The Platform Society: Public Values in a Connective World. Oxford: Oxford University Press.

Ward, S. C. 2012. Neoliberalism and the Global Restructuring of Knowledge and Education. London: Routledge.

Williamson, B. 2016. Digital education governance: data visualisation, predictive analytics, and 'real-time' policy instruments. Journal of Education Policy, 31 (2): 123-141. DOI: 10.1080/02680939.2015.1035758

Williamson, B. 2018. Silicon startup schools: technocracy, algorithmic imaginaries and venture philanthropy in corporate education reform. Critical Studies in Education, 59 (2): 218-236. DOI: 10.1080/17508487.2016.1186710

${ }^{1}$ Accordingly to a governmentality perspective, we conceive of the state here 'as an instrument and effect of political strategies that define the external borders between the public and the private and the state and civil society, and also define the internal structure of political institutions and state apparatuses' (Lemke 2007, 43).

${ }^{2}$ There are variations of BL among its advocates and users, as well as different names for what we refer to here as BL (e.g. personalised learning, on-line learning), see https://www.teachthought.com/learning/12-types-of-blended-learning/. 
${ }^{3}$ Consistently with a governmentality perspective (Foucault 2009; Dean 2010), with the term 'government' we refer here to 'any more or less calculated and rational activity [...] employing a variety of techniques and forms of knowledge, that seek to shape conduct by working through the desires, aspirations, interests and beliefs of various actors for definite but shifting ends' (Dean 2010, 18).

${ }^{4}$ Although we only gesture towards the latter here and address this more directly in another companion article.

${ }^{5}$ MSDF is a family foundation totally distinction from the Dell Foundation, but originally funded by the public sale of Dell Corporation shares by its founder Michael Dell. ${ }^{6}$ Being in the US Charter schools.

${ }^{7} \mathrm{KEA}$ is widely recognised as a leading school in instructional technology innovation. Following the KEA experience, all the schools of the KIPP network use technologyinfrastructured personalised learning principles in their classrooms. As reported on the KIPP LA website, in 2013, KIPP Comiensa Community Prep was featured as one of three schools featured by Silicon Schools Fund in a Massive Open Online Course (MOOC) about effective blended learning. KIPP LA is particularly active in sharing their best practices and in building partnerships around technological innovation. In 2013 KIPP LA, in collaboration with LAUSD, Partnership for LA Schools, and CFY-Los Angeles, received a planning grant from the Bill \& Melinda Gates Foundation to implement a school design and re-launch effort focused on personalised learning (https://www.kippla.org/approach/innovation). 